\title{
反渗透浓水回收利用系统
}

\author{
王金轶 骆青 \\ 安徽晋煤中能化工股份有限公司 \\ DOI:10.32629/eep.v2i8.395
}

[摘要] 反渗透浓水回收利用系统, 是从反渗透浓水经高压泉加压进入反渗透装置, 经反渗透处理产生大部分淡水分流到中间水池和淡水水箱 中,处理后产生的部分浓水排入过滤器反洗水池被利用。本文就反渗透浓水回收利用进行简要分析实施,仅供参考。

[关键词] 反渗透; 砂滤器; 电导率

\section{1 背景技术}

一般反渗透浓水排放量约 $100^{\sim} 125 \mathrm{~T} / \mathrm{H}$, 该水可以作为循环水补水使用, 由于该水浓缩倍率高, 有些循环水岗位因担心会引起设备结垢腐蚀, 而不 愿用浓水作为补充水使用, 于是就造成反渗透浓水管路憋压, 而引起浓水 防爆板憋炸的情况, 对反渗透的安全运行非常不利。为保障反渗透的安全 运行, 不得不采取排放部分浓水的办法。而大量的浓水被白白的排掉实在 是一种浪费, 无疑就增加了生产成本, 必须找到一种可行的方法将浓水回 收利用起来。

\section{2.实施方案}

为了弥补已有技术的不足, 提供了一种反渗透浓水回收利用系统。其 特征在于: 包括有从反渗透浓水总管中引出的一个分支管道, 分支管道进 来的水经控制阀进入管道泵进口, 经管道泵增压进入砂滤器, 浓水经砂滤 器除去机械杂质进入保安过滤器, 经保安过滤器除去铁胶体等物质后, 再 经高压百加压进入反渗透装置, 经反渗透处理产生的大部分淡水分流到中 间水池和淡水水箱中, 而处理后产生的部分浓水排入过滤器反洗水池也被 利用。

2. 1原理: 由于浓水管线比较细, 不经加压直接进入反渗透装置, 可能 会出现因压力不够而影响浓水再处理, 所以决定将浓水总管线接到反渗透 装置管道泵的进口管, 这样, 就可在浓水总压力低的情况下, 用管道泵对其 加压, 在浓水总压力高的情况下停运管道泵, 打开管道百旁路阀, 让浓水直 接进入砂滤器, 这样无论压力高低, 都能保证对反渗透浓水进行处理。

2. 2 优点: 本系统结构设计合理, 将浓水全部进行了再处理, 减少了废 水的排放量, 在节能减排降低制水成本方面, 成功的解决一级反渗透浓水 再处理利用的难题。

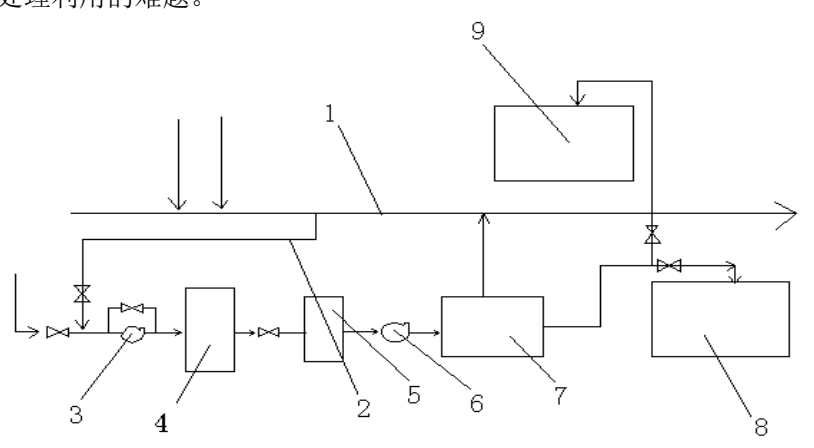

图 1

2. 3 实施: 参见附图1, 反渗透浓水回收利用系统, 包括有从反渗透浓水 总管 1 中引出的一个分支管道 2 , 分支管道 2 进来的水经控制阀进入管道原 3
进口, 经管道百 3 增压进入砂滤器 4 , 浓水经砂滤器 4 除去机械杂质进入保安 过滤器 5 , 经保安过滤器 5 除去铁胶体等物质后, 再经高压泵 6 加压进入反渗 透装置 7 , 经反渗透处理产生的大部分淡水分流到中间水池 8 和淡水水箱 9 中, 而处理后产生的部分浓水排入过滤器反洗水池也被利用。

例如: 装后的 $50 \mathrm{~T} / \mathrm{H} 反$ 渗透可处理一级反渗透浓水 $70 \mathrm{~T} / \mathrm{H}$, 可产淡水约 $45 \mathrm{~T} / \mathrm{H}$, 该淡水电导率为 $14 \mathrm{US} / \mathrm{CM}$ 左右, 完全符合淡水水质标准。在正常运行 情况下, 每小时可节约深井水 $70 \mathrm{~T}$ 。这样每天可节约深井水 $70 \times 24=1680 \mathrm{~T}$, 一年按 300 个工作日计算, 可节约深井水 $1680 \mathrm{~T} \times 300=504000 \mathrm{~T}$ 。可节省金额 50.4 万 $\mathrm{T} \times 0.65$ 元 $/$ 吨 $=32.76$ 万元。

\section{3 结语}

本系统结构设计合理, 将浓水全部进行了再处理, 减少了废水的排放 量, 在节能减排降低制水成本方面, 成功的解决一级反渗透浓水再处理利 用的难题。

\section{[参考文献]}

[1]赵建威. 反渗透浓水回收利用系统的应用 [ J ] 氮肥与合成 气,2019,47(01):18+30.

[2]高学慧. 反渗透浓水回收案例探究 [ J ]. 产业与科技论 坛,2015,14(24):37-38.

[3]梁二飞, 茅李峰, 凌妍, 等.零动力回收装置在反渗透浓水回收处理中 的应用 [J]. 南通职业大学学报,2017,31(02):91-93+99.

[4]王鹏, 李松良, 华常春. 反渗透系统的效能影响因素分析 [J].扬州职 业大学学报,2012,(2):38-42.

[5]朱慧晶,孟祥坤. 反渗透技术的主要性能指标及影响因素[ J]. 内蒙古 石油化工,2011,(2):108-109.

[6]郭瑞丽.反渗透浓水的预处理实验研究 [D]. 太原理工大学,2013.

[7]赵世刚, 石维平.反渗透浓水回收利用的探讨 [ J ]. 工业用水与废 水,2005,(03):58-59.

[8]张秀玲, 杨潘溪, 吴华. 反渗透工艺处理浓水节约水资源 [ J]. 氮肥技 术,2012,33(06):43-46.

[9]孙容, 李飞.反渗透浓水回用技术探讨 [J].电站辅机,2004,(3):51-53+56.

[10]权滨, 曾锋德.反渗透浓水回收利用技术在兰州石化公司除盐水装 置的应用[J].甘肃科技,2009,25(15):63-64.

\section{作者简介：}

王金轶(1975--), 男, 安徽临泉人, 汉族, 本科学历, 助理工程师、水煤 气中级技师, 研究方向: 半水煤气生产工艺; 从事工作: 煤化工生产 与研究。 